\title{
The Changing New Zealand National Security Environment: New Threats, New Structures, and New Research
}

\section{Author/s: William Hoverd}

To cite this article: Hoverd, W. J. (2019). The Changing New Zealand National Security Environment:: New Threats, New Structures, and New Research. National Security Journal, 1(1), 17-34. doi:10.36878/nsj201901.17

To link to this article: https://doi.org/10.36878/nsj201901.17

View CrossRef data: https://search.crossref.org/?q=10.36878\%2FNSJ201901.17\# 


\title{
THE CHANGING NEW ZEALAND NATIONAL SECURITY ENVIRONMENT: NEW THREATS, NEW STRUCTURES, AND NEW RESEARCH
}

\author{
William Hoverd ${ }^{1}$
}

This article is intended to supply readers of this new journal an updated broad contextual understanding of the recent changes to the New Zealand national security context. The international and domestic contexts in which New Zealand's national security are researched and operationalised have changed significantly since 2017. This article will review three areas of interest for the study of national security. It will discuss 1) the evolving national security context both global and local, 2) the changes to the New Zealand national security system, and 3) it will review recent New Zealand national security research. The article highlights a na-tional security system and a corresponding field of study that in addition to all the business as usual, will increasingly be focused on continuing structural reform and the threats posed by terrorism, cybersecurity, biosecurity and climate change. The article notes that while the national security context has changed significantly since 2017, the related field of research has evolved much more slowly. It concludes by arguing that an important function of this new journal will be to start to address this disjunction.

Keywords, New Zealand, National Security System, Cybersecurity, Terrorism, Climate Change, Mycoplasma bovis, Christchurch, Intelligence, New Zealand Defence Force.

\section{Introduction}

In 2017, along with Nick Nelson and Carl Bradley, I edited a volume on New Zealand National Security. ${ }^{1}$ The book was intended as an introduction to New Zealand's national security context and to some of the security and research issues that our contributors

\footnotetext{
$1 \quad$ Dr William Hoverd is a Senior Lecturer at the Centre for Defence and Security Studies at Massey University, Wellington, contact w.hoverd@massey.ac.nz. The author wishes to acknowledge and thank all those experts who spoke with him in preparation of this journal article. The open source contemporary professional insight that you generously offered informs my thinking about the whole picture of New Zealand's national security and, hopefully, reduces my chances of error and unfounded claims. Any remaining errors or mistakes in this manuscript are mine alone.
} 
saw as important at that time. Reflecting now on the book's content and focus, it is apparent that aspects of the national security environment both locally and internationally have changed dramatically. A number of events have evolved our focus and priorities and will likely result in structural change for the national security sector. Events such as the Christchurch Terror attack, the Mycoplasma bovis outbreak, the destruction of the Islamic State, the WannaCry and NotPetya malicious crypto worm malware attacks, and a rise of a new set of polarised domestic and international politics around economic protectionism have all significantly impacted the context in which national security issues are discussed. More broadly, the impact of climate change on security is also beginning to emerge as a future issue. This article details these events and themes and explains how they bring new pressures and concerns for those organisations tasked with delivering national security outcomes. These events and themes also demand that the academic scholarship devoted to this subject also evolve and adjust its assumptions. This article is intended to supply readers of this new journal an updated broad contextual understanding of the recent changes in the New Zealand national security context whether they be evolved threats or structural changes.

This article will review three areas of interest to update the context and our broader thinking about the study of national security in New Zealand (NZ). It will discuss 1) the evolving national security context both global and local, 2) the changes to the New Zealand national security system and, 3) review recent national security research. The article will then conclude by pointing to the future challenges for national security research in the New Zealand context.

This article utilises the Department of Prime Minister and Cabinet's (DPMC) definition of national security to understand its field of study. ${ }^{2}$ The national security domain is a broad church of study and New Zealand's perspective is to have an all-hazards all-risks approach to national security. ${ }^{3}$ Theoretically, it assumes that national security occurs at the intersection of the domestic and international. ${ }^{4}$ But the term itself and any corresponding field of research addresses uncertainty, insecurity and a shifting series of concerns. ${ }^{5}$ This effectively means that the field of study can quickly evolve traditional security locations of defence, policing, intelligence and border security out into a number of domains including the economy, agriculture, climate, social media and the ramifications of a malware release anywhere in the world. The national response plan to the impact of Mycoplasma bovis incursion on our economy and the intelligence resources required to combat this challenge is an example of how security issues evolve. In the next section of the article, we move to discuss the global and local changes that have impacted upon New Zealand's national security.

\section{The Global Security Context}

The international context in which New Zealand's security is researched and operationalised has changed significantly since 2017. Over the last two years New Zealand has 
seen risks to its security arise from tensions with North Korea (nuclear and cyber), China (trade war), Iran (gulf and nuclear tensions), Russia (election interference, cyber and hybrid warfare) and internal conflicts with Iraq (Islamic State, or ISIS), Syria (civil war) and the Sudan (civil war) as well as regional concerns in terms of Papua New Guinea (security for APEC) and the Pacific (disaster relief and aid). These events and threats directly and indirectly impact our foreign policy, allocation of domestic resources and the focused efforts of our national security agencies. Internationally, the two most significant events that have changed New Zealand's national security functions have been the physical degradation of ISIS and the deployment of global cyber-attacks that potentially signal a sea change in the ability and willingness of certain states to utilise and defend against these capabilities. This section focuses first on ISIS and terrorism, second on cybersecurity, and then a third more diffuse area of insecurity related to the rise of economic protectionism and polarised politics.

Globally, the war against the ISIS has been conducted and won, at least in terms of the territory that ISIS held in the Middle East. The threat of ISIS was a key part of John Key's national security thinking in 2014, and it seems now with the announcement of the New Zealand Defence Force's (NZDF) withdrawal from Iraq, ${ }^{6}$ that the threat has subsided. Nevertheless, its leader Abu Bakr al-Baghdadi remains unaccounted for and is still potentially at large. ${ }^{7}$ For New Zealand, questions remain about the final fate of Red Cross nurse Louisa Akava from Otaki. ${ }^{8}$ Despite the cessation of open conflict, it remains to be seen how much global terror and ideology will still be spread by ISIS.

Closer to home, ISIS has had a strong regional support base in South East Asia. In the Philippines, the Moro conflict between the Government and the Islamic State Jihadists (led by the Maute brothers) deescalated after the battle of Marawai city that occurred between May and October 2017. ${ }^{9}$ This open warfare against ISIS had little publicity here in NZ, but there remain scattered remnants of these groups across the Philippines and Indonesia and, as such, these nations remain potentially vulnerable to future terrorist attacks. Issues such as how and whether to repatriate ISIS's Foreign Fighters are contemporary challenges i.e., Kiwi ISIS Jihadi Mark Taylor. ${ }^{10}$ Despite the fact that ISIS has been physically degraded, it still has the ability to inspire terrorist acts. The recent Sri Lankan bombings, demonstrate the ongoing potential for catastrophic terrorism related damage that might occur within the region. ${ }^{11}$ Critically, the degradation of ISIS does little, if anything, to mitigate the ongoing threat that lone wolf actors can pose to nation states. i.e., the March $15^{\text {th }} 2019$ Christchurch mosque attack. Terrorism, whether ISIS inspired or not, remains a present global threat and is now more consequential in $\mathrm{NZ}$ than we could have ever guessed it would be.

Globally, cybersecurity is a growing threat. Two severe global cyber-attacks were delivered by nation states in 2017. The cybersecurity threat should be understood as present and as dangerous as terrorism, if not more threatening because of its potential scale. The recent WannaCry (2017) and NotPetya (2017) malware crypto worm cyber-attacks 
have been attributed to Russia and North Korea and represent the two most costly cyber-attacks that the world has currently experienced. ${ }^{12}$ The WannaCry attack (May 2017, US $\$ 4-$ US $\$ 8$ billion) was a ransomware crypto worm that spread globally, effectively locking down industry computers such as the UK's National Health System and subsequently Boeing in 2018. ${ }^{13}$ The sheer indiscriminate scale and damage of this attack attributed to a nation state (North Korea), demonstrated the global threat that such malware could potentially cause, specifically, if the attack was targeted at a state's critical infrastructure. In addition, the NotPetya attack (June 2017, US\$10 billion) also originally appeared to be a ransomware attack, but in actual fact, it was a 'wiper' which permanently wiped the content on computer hard drives..$^{14}$ NotPetya was primarily deployed at a series of direct targets in the Ukraine removing part of the government and civil society's software infrastructure. The collateral damage spread by the cryptoworm spread across the globe, i.e., Danish international shipping giant Maersk was cruelly impacted by the worm. ${ }^{15}$ NotPetya was subsequently attributed by the CIA to Russian hybrid warfare action. ${ }^{16}$

These cyber-attacks are globally ruinous and effectively deniable for those actors who deploy them. While these two attacks did not take lives specifically, both disrupted the software infrastructures of corporations and governments. The implication here being that if the actors who deployed these attacks changed targets to shutting down critical infrastructures such as transport grids, power stations, hospitals etc then catastrophic widespread, direct and collateral damage could be caused. The potential for indiscriminate damage with such attacks is unimaginable. As a response to NotPetya, Five Eyes cyber-condemnation of Russia occurred on 18 April 2018. ${ }^{17}$ Moreover in 2018, the Government Communication Service Bureau (GCSB) ${ }^{18}$ Labour Coalition Government ${ }^{19}$ and $\mathrm{NZDF}^{20}$ have all at various times referred to Russia and/or North Korea as potential sources of cyber threat. Given the widespread global damage caused by WannaCry and NotPetya and the fact that these cyber capabilities/weapons have recently been deployed and could be again, New Zealand is wise to be vigilant and build cybersecurity infrastructures because the very nature of the Internet Of Things potentially brings these threats into the homes and pockets of all of our citizens.

There is a third significant change in the global security environment which needs attention as well, but it is more diffuse because it creates insecurity rather than threat or risk per se. There has been a rise of domestic polarised politics and economic protectionism from nation states such as the United States (US) and the United Kingdom (UK) which are both a product of and perpetuate insecurity. The rise of economic protection, the polarisation of politics and concerns about free speech have repercussions for the study of security. The rise of economic protectionism has impacted New Zealand in terms of the collapse of the Trans Pacific Partnership in 2017 after the US withdrawal. ${ }^{21}$ While this deal has been renegotiated and reconfigured as an eleven-nation Comprehensive and Progressive Trans-Pacific Partnership, the rise of US (steel tariffs and their ongoing trade 
war with China) and UK's (Brexit) economic protectionism will continue to have ongoing impact upon New Zealand's economic security where these traditional partners are continuing to renegotiate and redefine their economic relations. These political and economic challenges are both domestic and international, and economic security impacts national security. The economic debates are tied into a polarisation of politics within these nations which is characterised by a growing divide between left and right within a nation's political sphere. ${ }^{22}$

This polarisation is characterised by a lack of desire to engage constructively with political opponents and often results in a vilification of social groups. i.e., immigrants. Arguably, this polarisation occurs across the medium of social media and impacts more heavily on marginalised communities. But it also manifests internationally as tensions over trade and borders (i.e., Brexit and Trump's proposed Mexican border wall). Key questions for the contemporary study of New Zealand national security is whether economic protectionism is driving international insecurity and whether the polarisation of politics has adversely impacted free speech, encouraged extremist views and incited dehumanisation of social groups? Certainly, these issues all surround the commentary that has arisen after the Christchurch terror attack. We now turn from this discussion of the global to discuss local events impacting how we understand national security.

\section{Changes in the Local Security Context}

Our local national security context has been characterised by terrorism, climate change, defence concerns, cybersecurity, Mycoplasma bovis, intelligence reform and two major government inquiries that may evolve how we understand and enact security in New Zealand. There was a change of government in 2017, with a new Prime Minister Jacinda Ardern of the Labour Party leading a coalition government alongside New Zealand First and the Green Party. Regionally, the Pacific Reset ${ }^{23}$ has focused New Zealand Government initiative and this policy has, in turn, influenced defence policy in terms of proposed capability purchases ensuring that in addition to offering combat functions they are also to provide humanitarian and disaster relief tools. In addition, Minister responsible for the New Zealand Security Intelligence Service (NZSIS) Andrew Little noted in 2018, that the greatest threats facing New Zealand's security were terrorism and cybersecurity. ${ }^{24}$

In response to global cybersecurity concerns and their potential impact on domestic infrastructure, the Government Communications Security Bureau's (GCSB) National Cyber Security Centre has purchased and activated its CORTEX cyber defence mechanism. ${ }^{25}$ CORTEX is designed to protect nationally significant Government and Private Sector organisations from malware attacks similar to WannaCry or NotPetya. This defence of key infrastructure is then supported by broad initiatives such as those provided by the Ministry of Business, Innovation and Enterprise's (MBIE) Computer Emergency Response Team (CERTNZ) ${ }^{26}$ in combination with a broader Cyber Security 
Strategy refresh occurring across Government. ${ }^{27}$ The 2018 Strategic Defence Policy Statement indicated that the NZDF would also be investing in new cyber capabilities. ${ }^{28}$ The 2019 budget came with additional funding for cybersecurity in terms of strengthening CERTNZ and the development of the national cybersecurity strategy. Despite all these initiatives, it remains to see how effective New Zealand's cybersecurity infrastructure actually is and this additional 2019 funding suggests that there is still significant effort required in establishing these infrastructures.

In terms of terrorism, the $15^{\text {th }}$ March 2019 Christchurch attacks on the Al Noor Mosque and the Linwood Islamic Centre have profoundly changed the nation's national security reality. The lone attacker managed to slaughter 51 New Zealand Muslims and injure another 49 in under an hour. He livestreamed the attack on Facebook and also wrote a manifesto which he had distributed online. Alongside 51 murder charges and 40 attempted murder charges, the attacker has been charged with committing a terrorist act. ${ }^{29}$ The defendant has pleaded not guilty to all charges. The trial date is set for May $4^{\text {th }} 2020 .^{30}$ At the time of writing this article, the long term consequences of this attack for national security are still uncertain. The consequences will certainly be a test of our judicial and legislative infrastructures. But it is already evident that the downstream legislative, structural and strategic outcomes resulting from this terror event will produce fundamental sea changes for all those involved in enacting national security for the foreseeable future.

The New Zealand public have already witnessed five direct actions from Government resulting from the attack:

- National acts of reconciliation with the Christchurch Muslim community ${ }^{31}$

- The banning of the manifesto ${ }^{32}$

- The banning of semi-automatic and assault rifles ${ }^{33}$

- The Christchurch Call ${ }^{34}$

- The Royal Commission of Inquiry into the Attack on Christchurch Mosques ${ }^{35}$

All of these government actions deserve more consideration than there is space for here in this article because of their significant downstream impact upon national security thinking and structures. Consequently, detailed investigations of these various actions will inform national security scholarship in the near future. If we discuss them briefly, we can note that significant political and community acts of remembrance, reconciliation and unity occurred shortly after the attacks. There was a national outpouring of positive sentiment and goodwill as a response to the attacks that was heart-warming, but nevertheless in need of critical investigation. Sustaining and, perhaps even institutionalising, the informal and spontaneous gestures of social generosity, inclusion and integration that occurred after Christchurch could be essential for sustaining goodwill, and creating a socially cohesive population that by celebrating its diversity effectively rejects terror and hate. In terms of hate, the Chief Censor was also quick to censor the 
attacker's manifesto ${ }^{36}$ as the government was to ban and set in place a buyback for a variety of firearms in direct response to the attack and as a firm endeavour to increase the safety of the community. In the international sphere, the New Zealand Government has pursued the Christchurch Call to ask other governments and global online service providers to begin to address the issue of extremist and terrorist content being available online. Eighteen nations and some large online service providers (e.g., Google, Facebook, Twitter, and Amazon) have made a commitment to develop infrastructures to counter violent extremism online. ${ }^{37}$

Of all the actions coming out of Christchurch, crucially, it will be the Royal Commission of Inquiry's findings that is likely to set the direction for a political discussion around whether additional government action or reform might need to occur that will impact the national security sector. In particular its consideration of what was known and could have been done about the attack and then in terms of what the terms of reference state as "... what additional measures should be taken by relevant state sector agencies to prevent such attacks in the future." ${ }^{\prime 3}$ At this stage, one can only guess at what the Inquiry will find. Nevertheless, we can be sure that the results of the inquiry will influence future national security direction and infrastructure and, when they come out, they will require close scrutiny from decision makers, scholars, the public and New Zealand's Muslim community. It is likely that we will see recommendations influencing national security policy around a number of areas including immigration, counter terrorism mechanisms, legislative change and social cohesion.

Turning now to look to some of the other evolutions in local national security we discuss defence and biosecurity. In terms of defence issues, the last two years have seen a continued commitment to the Building Partner Capacity mission in Iraq and engagement in Afghanistan. ${ }^{39}$ Although, it has been signalled that the Iraq deployment will cease in 2020 and the ongoing Afghanistan deployment will change focus. ${ }^{40}$ Through this period, the government has given regular attention to the role and investment in provisioning of the NZDF through the Strategic Defence Policy Statement ${ }^{41}$ and the Defence Capability Plan 2019. ${ }^{42}$ Both documents, signal an intention for defence priorities to be aligned with the Pacific Reset and for interoperable compatibility with our Five Eyes partners. The refreshment of the defence asset base and a detailed discussion of region tensions between major powers and the future effects of climate change on the $\mathrm{Pa}$ cific are the dominant foci of these documents..$^{43}$ Nevertheless, there remains a tension about the role of the NZDF, with the emphasis on regional humanitarian and disaster relief functions, maritime patrol, and combat capability roles all having to be carefully balanced in the future. ${ }^{44}$

More controversially, allegations in the book Hit and $R u n^{45}$, written by investigative journalists Jon Stephenson and Nicky Hager, have led to an Inquiry into Operation Burn$h^{4} m^{46}$ which investigates an action of the New Zealand Special Operation Forces (NZSOF) in Afghanistan. The results of this Inquiry are due to be reported to the Attorney 
General by $31^{\text {st }}$ December 2019. At this stage, it is futile to try and closely investigate the nature of the inquiry itself (simply because it's impossible to objectively know whose agenda to trust), but its very existence points to a larger focus for the study of national security. That of the role of the Fourth Estate, in this case the New Zealand media, in holding the government to account. Importantly, the role of the Fourth Estate is to scrutinise the state's language and action as an accountability function. The Gordian knot of the media challenge to the national security sector, is that due to the nature of the sector's work it necessarily has to respond to media in a closed manner. In turn, because of its very nature the national security sector is evasive and non-transparent in its responses to media scrutiny. This elusiveness then perpetuates a cycle of additional media criticism and attempts to find out more information. Elsewhere, I have written about how these challenges result in national security discourse being contestable. ${ }^{47}$ Elusiveness inevitably leads to a lack of trust and this then compounds to a point, that when national security statements are made explicit by government they are not necessarily trusted either. Official Information Act (OIA) requests for information, media scrutiny, leaks and the potential for sensationalism will continue to be a characteristic of this type of criticism. The unfortunate consequence is that when it comes to Inquiries such as that into Operation Burnham, even the informed viewer cannot gain any form of objective insight into the matter at hand and, as such, is unable to discern who to have trust or confidence in.

The nature of what constitutes a national security threat in New Zealand has also evolved. For example, biosecurity is now a major concern. On July $22^{\text {nd }} 2017$, Mycoplasma bovis was found on a farm in South Canterbury. ${ }^{48}$ While not a food safety risk, Mycoplasma bovis is a bacteria that can cause a range of very serious conditions to cattle. ${ }^{49} \mathrm{On}$-farm, it is spread through fluids i.e., saliva and milking machines. Off-farm, it is spread through the movement of cattle and equipment that has been in contact with other infected animals. ${ }^{50} \mathrm{~A}$ recent estimate of the cost of this bacteria outbreak falls between $\$ 200$ million and $\$ 1$ billion to the NZ economy..$^{51}$ The Ministry of Primary Industries (MPI) calculates the scale of the outbreak is as follows:

At the time of writing, MPI's latest update says there are 173 properties confirmed to be infected by M.bovis, 134 of which have been cleared of the disease, with 104,583 animals culled. Eighteen of the 39 "active" properties are in Canterbury.

Notices of direction have been issued restricting animal movements on 229 properties, thought to have received cattle from infected farms, while another 592 properties thought to be at risk are being tested. ${ }^{52}$

MPI has been the lead agency in the response to the Mycoplasma bovis outbreak. This role originally involved containment, detection and prevention. Now MPI has been tasked with eradicating the bacteria completely from New Zealand farms. ${ }^{53}$ Interestingly, we see that as one part of its response to the outbreak that MPI has broadened its 
intelligence capabilities (from the fishing space) to better understand the issues around Mycoplasma bovis and agriculture in general. It seems that this development of intelligence capabilities is occurring across Government. In addition to the long standing intelligence functions of New Zealand Police and the NZDF, these functions exist across a wide range of government agencies, New Zealand Transport, ${ }^{54}$ Department of Corrections ${ }^{55}$ NZ Customs ${ }^{56}$ Ministry of Primary Industries ${ }^{57}$ and Ministry of Business Innovation and Enterprise. ${ }^{58}$ Given a strong recent focus on oversight and transparency of our intelligence agencies, ${ }^{59}$ one would hope that these disparate intelligence units would also be subject to similar accountability and standards of good conduct measures. This leads us now to our next section, the discussion of structural changes in the New Zealand national security sector.

\section{The National Security System}

In 2016, the Cullen Reddy Report argued for substantial changes to occur around the legislation pertaining to New Zealand's Intelligence Agencies ${ }^{60}$ This led to the Intelligence and Security Act $2017^{61}$ replacing four Acts governing these agencies, ${ }^{62}$ and now this one Act covers the roles, functions and responsibilities of the NZSIS and the GCSB. The stated intention of the Act is to both empower these agencies to protect New Zealand, but also to provide a mechanism to reassure the New Zealand public that their actions are lawful. The office of the Inspector General of Intelligence and Security (IGIS) ensures that these actions are conducted lawfully and properly ${ }^{63}$ The Act ensures that functions are shared across both agencies and suggests that cooperative mechanisms for coordination with New Zealand Police and the NZDF are properly facilitated. That being said, it has been recently argued that New Zealanders still have little idea of the nature of surveillance that is now possible under the Act. ${ }^{64}$

Clearly, the role of intelligence sharing and cooperation mechanisms is essential to the national security functions of government. We might ask the question is the term 'national security' simply a synonym for intelligence coordination? To some extent this is an unfair claim, but when we stop to consider that at the strategic level of government all decisions need to be informed by, integrate and utilise all the intelligence available then we need to acknowledge that it is impossible to separate national security policy and decisions from its intelligence function. We should think about these functions as providing national security coordination by integrating and using intelligence led decisions and policy.

In terms of DPMC's responsibility for national security, they published the National Security System Handbook in 2016, which details the various functions of government that are activated in response to particular security concerns. ${ }^{65}$ The document has become a key text of focus for those researching national security in New Zealand. ${ }^{66}$ The challenge that such a document has is - keeping up-to-date, and already the National Security System Handbook does require updating. It needs to reflect that two groups in 
the national security system no longer exist; both the Official's Committee for Domestic and External Security Coordination - Governance (ODESC-G) and the Strategic Risk and Resilience Panel (SRRP) were dissolved in 2017. The refresh was to be a priority for DPMC before the Christchurch attack. But today, it is difficult to determine what effect the Christchurch attack and the Royal Commission will have on such priorities, particularly if the Commission were to recommend structural change at the highest national levels.

Turning to investigating these National Security System changes further. ODESC-G was a Chief Executive Governance Group which met regularly to identify and prioritise national security concerns ${ }^{67}$ The SRRP was a committee of independent members from outside government whose function was to provide ODESC-G with advice by critically assessing its national security priorities.$^{68}$ Understandably, the role of the ODESC-G has been somewhat rolled up into the ODESC meetings which directly report to Cabinet. ${ }^{69}$ It is also understandable that SRRP, whose role was to advise ODESC-G, would be removed as it no longer had a committee to which it needed to report. Nevertheless, the loss of an independent advice function is regrettable and perhaps in the future should be revisited. In 2018, the IGIS appointed such an independent reference panel of experts to broaden that office's access to independent advice and thought leadership. ${ }^{70}$

The emergency management aspect of national security has yet to receive significant attention. In November 2017, it was recommended that Civil Defence and Emergency Management be reformed into the National Emergency Management Agency (NEMA). ${ }^{71}$ The proposal is to increasingly shift to a proactive system of emergency management. ${ }^{72}$ This project acknowledges that there are significant coordination mechanisms that need to be streamlined both in terms of national systems and centres as well as through local coordination at the regional level through mayors and iwi. ${ }^{73}$ The NEMA function is a fundamental subset of the national security system as, through both its central and regional apparatus, it provides the environmental support required for domestic national security events. And if we take the example of Christchurch, we see that these apparatus are not just utilised in response to natural disasters such as fires and earthquakes, but they were also heavily relied upon in the terror attacks. In the near future, the Coordinated Incident Management System (CIMS) Response Framework Edition Three will be published furthering our understanding of this dimension of national security. It remains to be seen how effectively NEMA will work alongside designated lead agencies when the national security system is next activated.

\section{National Security Research}

While the local and global security contexts have moved rapidly since 2017, the national security research field has moved slowly. Robust social scientific research agendas are hamstrung by the challenge of developing an evidentiary basis. The field of study is a classified domain of government knowledge and operations and secrecy significantly 
impacts our researchers' abilities to access and generate primary data from which they can advance knowledge. Nevertheless, I continue to argue that there are two primary approaches to national security research that occur in New Zealand: 1) Agency oriented critique and 2) Objective critical assessment. ${ }^{74}$ Agency oriented critique occurs "when a researcher is located within, or is sponsored by an agency". ${ }^{75}$ Whereas objective critical assessment is the type of research that occurs from a researcher located outside a security agency.

Agency insider researchers have the ability to access and generate authentic evidence-based insights to national security, but they have to carefully monitor that their work is open source and sustains rather than conflicts with their role as an employee of that organisation. A recent NZDF People Research Conference offered a vibrant and diverse portfolio of interdisciplinary research and researchers engaged with various aspects of the human dimensions of defence in New Zealand. Other recent agency related initiatives see security agencies sponsoring predefined research projects or topics through the mechanisms of New Zealand Police's Evidence Based Policing Centre ${ }^{76}$ or the Multi Agency Research Network at Massey University. Both mechanisms are yet to publically deliver substantial outputs, but if and when they do, the evidence base of these products should benefit from the unique access to primary data that they offer. Nevertheless, we must also be aware that there is a politics to these mechanisms as they have an industry focus. Damien Rogers has warned that there are risks associated with this type of research, in that agency sponsorship could discourage critical analysis and will only resource research that is of "interest" to those agencies. ${ }^{77}$ This means that university researchers engaging with these mechanisms must be alert to potential challenges around their Education Act mandate to be a critic and conscience of society, and align their research priorities accordingly.

By contrast, objective critical assessment occurs when a researcher approaches the field of national security from the outside. "The scholarship's purpose is to deconstruct the object of study into its constitutive parts to create and reveal a broad understanding of all the perspectives contained in its parameters." ${ }^{38}$ The approach treats security discourse as constructed and contestable and it can often be quite critical in nature. The methodological challenge for objective critical assessment approach is in its evidentiary basis. Gaining access to primary data without security agency support is extremely difficult. This means that this type of research when done well tends to focus on theoretical and/or discourse analysis (studying the words of government through policy and statements) approaches to knowledge. Even when done well, these types of approaches must mitigate two challenges: 1 ) a tendency towards criticism which, with the benefit of hindsight, the research points simply to shortcomings, and 2) that this type of research is often looking back into the past and risks a disconnect from current contemporary concerns. In the worst cases, when objective critical assessment lacks a robust eviden- 
tiary basis, this type of research can tend towards the descriptive becoming what is effectively opinion or expert commentary.

Turning now to discussing some recent examples of objective critical assessment as it applies to national security research. Robert Lyon's thesis examined the national security rhetoric that occurred in the Key/English National Governments between 2008 and $2017 .{ }^{79}$ Lyon argues that in the rhetoric of this period that a language of riskification occurred around national security. For Lyon, riskification occurred where notions of security were extended to policy and discourse that one might consider not traditionally associated with security. Explicit examples of Lyon's argument can be found in DPMC's definition of national security which extends an all hazards all risks approach to a whole of society understanding of national security. Practically, we can find examples of this approach through the work of the Ministry for Primary Industry's (MPI) work on biosecurity, for example Mycoplasma bovis. Importantly, Lyon's work shows that alongside the explanatory framework offered by securitisation theory, national security scholarship should also be alert to the incorporating theories of risk especially in an all-hazards all-risks environment.

This focus on the non-traditional security issues is going to increase over the next few years. In 2018, it was supported by the contributions to the second Massey University national security conference that were subsequently published in Line of Defence Magazine. ${ }^{80}$ In the conference, it was noted that scholarship needs to focus both on the traditional and non-traditional from issues such as cybersecurity, counter-terrorism and nuclear politics to climate change, human security and our models of citizenship. Issues around biosecurity, protecting the maritime and space domains and pandemics also loom large as future non-traditional security issues. ${ }^{81}$ Added to these issues recent conferences at Waikato and Massey Universities have focused on external exploration of the issues surrounding the technologisation of security ${ }^{82}$ and the role of religion and security. ${ }^{83}$

National security scholarship also allows researchers the ability to initiate debate around the future avenues for the national security architecture. For example, Chris Rothery's thesis proffered the argument that New Zealand needs a national security strategy to overcome the fact that the national security system is primarily reactive and the lack of collaboration that he sees occurring from national security agency silos ${ }^{84}$ Rothery's research explored the decision making criteria that a New Zealand National Security Strategy should include and he pointed to the theoretical basis upon which it should be developed. Rothery, and also in earlier works by Johanson, ${ }^{85}$ quite rightly identify that there is a gap here in the national security structure and this has allowed them to publically interrogate this question. In this journal issue, Rothery continues this examination, proposing a structured approach to how a strategy could be formulated. ${ }^{86}$ 
The question becomes should this gap in our national security architecture be filled? The benefits of such an approach would be to guide policy, create shared national security goals, induce cooperation, reduce the risk of silos and potentially offer alignment with the strategies of our Five Eyes partners. The arguments against such a strategy is that it would be costly to develop, would require an infrastructure to sustain it, that it would require a level of complexity and negotiation across government, it would require consultation across government and civil society, and it would need to be publishable which means it would be relatively high level. Lastly, it would provide a document to which a government could be called to account which likely would lessen political support. There is a real risk that without sustained political and economic support and bureaucratic infrastructure such a strategy would quickly become a historical artefact. For such a strategy to be implemented it would need political will and it would need some form of evidence base suggesting that the benefits of such a strategy outweigh its costs. The results of the Royal Commission of Inquiry, whenever they are released, will likely indicate whether there is a mandate for developing either a national security strategy or a counter-terrorism strategy.

I maintain that both types of scholarship (agency oriented critique and objective critical assessment) remain essential to a comprehensive understanding of national security research in the New Zealand context. Insider and outsider research may have different priorities and outcomes but ultimately, they are complementary. Together these two types of research cover the limitations and subjectivities of the other. In combination, they allow us to understand the different perspectives of the other and can, when done well, offer a comprehensive understanding of security issues both from an agency perspective and an outside view.

Before we turn away from discussing national security research, I want to comment on a pressing pedagogical issue for national security scholarship that I have been noticing more and more. As a researcher with the responsibility for teaching graduate research methods in Defence and Security, it is my observation, that across all forms of domestic security scholarship that there is engrained challenge with researchers making time to read comprehensively. Nobody is immune, it is endemic, and we all struggle with it. Commonly, this lack of reading occurs around either a lack of engagement with relevant theory or the counter arguments against their position, but unfortunately quite often reading omissions are more basic and unforgiveable. The reasons for a lack of reading are complex. The study of national security is multi-disciplinary and the pursuit of mastery of multi-disciplinary domains of knowledge are beyond the time available to most researchers. More practically, they are related to the pressures of increasing workloads of academic staff and for students the challenge of balancing work, study and family life are often unsustainable, and these pressures when combined with a changing media and educative environment where an emphasis on digital engagement is a primary focus lessens any emphasis to read. The consequences of this lack of reading however are 
dramatic for researchers. Gaps in bibliographies weaken the authority of the researcher. Reading gaps weaken the efficacy of the research as they can omit related studies that could nuance one's research question, methodology or findings. Ultimately, a lack of reading reduces the credibility of the research product and the researcher. Moreover, this lack of reading has real consequences when it comes to the fact that national security research engages with wicked problems and can influence media engagement and government action. Across the board, it is critically important that we encourage all researchers to read more, both widely and deeply. If I could change one thing about national security scholarship it would be to urge all national security researchers that before they speak or write just to review the literature one more time. It will refresh, strengthen and mature your analysis and this will benefit everybody. This journal offers us all the opportunity to broaden our reading around national security.

\section{Final thoughts}

This article has reviewed three areas of interest to update the context and our broader thinking about the study of New Zealand national security: 1) The evolving national security context both global and local, 2) the changes to the New Zealand national security system, and 3) it reviews recent national security research. In each section, the article pointed to the various future challenges for national security research in the New Zealand context. However, as I conclude writing this article it's content feels very much a placeholder between our original volume on national security and what will happen after the results of the Royal Commission of Inquiry into the Attack on Christchurch Mosques $^{87}$ are made available. I am of the view that it is these results that are likely to drive the major priorities for New Zealand national security for the medium term. And at this stage, it is difficult to predetermine what these priorities might be. Structurally, I think we can expect right wing extremism to be a major focus of national security discourse, at least in the short to medium term. As a corollary, we should expect to hear national security concerns about "radicalisation" be substituted with a discourse concerned with "extremism." This shift of term to extremism opens more of a broad church of focus, where radicalisation does seem to be a product of a particular focus on Muslim populations. Given that Christchurch has been, and will continue to be, a major sea change in how we think about and do national security, mechanisms will been needed to provide independent thought leadership focusing on the ramifications of this event. If we look to the long term, the effects of climate change are going to increasingly impact our discussions around "security events" and we can see that the National Security System (through NEMA) and the NZDF (through its 2019 and 2018 publications) is being increasingly focused around the assets and infrastructure to address this issue. In the future, given that we are an island nation with a responsibility to the South Pacific there will inevitably be increasing national security infrastructure devoted to addressing the effects of climate change. Importantly, it will be one role of this new national security journal to provide the incremental advances in research occurring in this space 
and to provide an evidence basis for these contemporary concerns and this journal also offers a natural place for us all to remedy this concern around a lack of reading.

1 Willim Hoverd, Nick Nelson and Carl Bradley, eds, New Zealand National Security: Challenges, Trends and Issues, (Auckland: Massey University Press, 2017).

2 National Security System Handbook (Wellington: Department of the Prime Minister and Cabinet, 2016).

3 See https://dpmc.govt.nz/our-programmes/national-security-and-intelligence/national-security/national-security-objectives (accessed 1st July 2019).

4 Matthew Sussex, Michael Clarke \& Rory Medcalf (2017) National security: between theory and practice", Australian Journal of International Affairs, 71:5, 474-478, DOI: 10.1080/10357718.2017.1347139

5 Hoverd, WJ. (2017). Introduction. In W. Hoverd, N. Nelson, \& C. Bradley (Eds.) New Zealand National Security: Challenges, Trends and Issues. (pp. 19 - 59). Auckland: Massey University Press

6 New Zealand to withdraw from Iraq in June 2020. 10th June 2019. Available at https://www.beehive. govt.nz/release/new-zealand-withdraw-iraq-june-2020 (accessed 1st July 2019).

7 Frank Gardener. Abu Bakr al-Baghdadi: Why is it so difficult to track down IS leader? 1st May 2019. Available at https://www.bbc.com/news/world-middle-east-48104463 (accessed 1st July 2019).

8 Tracey Watkins. The Secret Hostage. Available at https://interactives.stuff.co.nz/2019/the-secret-hostage/ (accessed 1st July 2019).

9 Carmela Fonbuena. Marawi one year after the battle: a ghost town still haunted by threat of ISIS 18th May 2018. Available at https:/www.theguardian.com/global/2018/may/22/marawi-one-year-siege-philippines-ghost-town-still-haunted-threat-isis (accessed 1st July 2019).

10 John Battersby and Rhys Ball. The Problem of the Prodigal ISIS Supporters. 6th March 2019. Available at https://www.stuff.co.nz/national/111039630/the-problem-of-the-prodigal-isis-supporters (accessed 1st July 2019).

11 Alena Drieschova. Sri Lanka's Easter Sunday attacks were meant for international audience, but have local consequences. June 6 2019. Available at https://theconversation.com/sri-lankas-easter-sunday-attacks-were-meant-for-international-audience-but-have-local-consequences-117704 (accessed 1st July 2019).

12 The Five Most Notorious Cyber Attacks. November 6th 2018. Available at https://www.kaspersky. $\mathrm{com} / \mathrm{blog} /$ five-most-notorious-cyberattacks/24506/ (accessed 25th June 2019).

13 Lee Matthews. Boeing Is The Latest WannaCry Ransomware Victim. March 30th 2018. Available at: https://www.forbes.com/sites/leemathews/2018/03/30/boeing-is-the-latest-wannacry-ransomware-victim/\#771f28026634 last accessed 1st July 2019.

14 New Petya / NotPetya / ExPetr ransomware outbreak. June 27th 2017. Available at: https://www. kaspersky.com/blog/new-ransomware-epidemics/17314/ (accessed 25th June 2019).

15 Lee Matthews. NotPetya Ransomware Attack Cost Shipping Giant Maersk Over \$200 Million.

August 16th 2017. Available at https://www.forbes.com/sites/leemathews/2017/08/16/notpetya-ransomware-attack-cost-shipping-giant-maersk-over-200-million/\#6749c914f9ae (accessed 1st July 2019).

16 Ellen Nakashima. Russian military was behind 'NotPetya' cyberattack in Ukraine, CIA concludes. January 12th 2018. Available at https://www.washingtonpost.com/world/national-security/russian-military-was-behind-notpetya-cyberattack-in-ukraine-cia-concludes/2018/01/12/048d8506-f7ca-11e7-b34ab85626af34ef_story.html?utm_term=.26d65cb883f8 (accessed 1st July 2019).

17 Paul Waldie. Trudeau and key allies condemn Russia's role in cyberattacks, poisoning. 18th April 2018. Available at https:/www.theglobeandmail.com/world/article-trudeau-and-key-allies-condemn-russias-role-in-cyberattacks/ (accessed 1st July 2019).

18 Government Communications Security Bureau. February 16th 2018. New Zealand joins international condemnation of NotPetya cyberattack.https://www.gcsb.govt.nz/news/new-zealand-joins-international-condemnation-of-notpetya-cyberattack/ (accessed 1st July 2019). 
19 Department of the Prime Minister and Cabinet National Cyber Policy Office. Proactive Release. April 2018. https://www.dpmc.govt.nz/sites/default/files/2018-04/ers-18-paper-refresh-of-new-zealandscyber-security-strategy-and-action-plan_1.pdf

20 New Zealand Government. Strategic Defence Policy Statement. 2018: 18.

21 Chow, Daniel Chee King and Sheldon, Ian and McGuire, William, How the United States Withdrawal from the Trans-Pacific Partnership Benefits China (August 7, 2018). University of Pennsylvania Journal of Law and Public Affairs, 2019 Forthcoming; Ohio State Public Law Working Paper No. 451. Available at SSRN: https://ssrn.com/abstract=3228007 or http://dx.doi.org/10.2139/ssrn.3228007

22 Pew Research Centre. Polarization in the American Public. June 12th 2014. Available at https:// www.people-press.org/2014/06/12/political-polarization-in-the-american-public/ (accessed 1st July 2019).

23 Winston Peters. Shifting the Dial. 1st March 2018. Available at https://www.beehive.govt.nz/speech/ shifting-dial (accessed 1st July 2019).

24 Andrew Little "Andrew Little addresses the National Security Conference." Line of Defence Magazine, Winter 2018 Volume 1 Issue 8. Pp. 33-35.

25 Government Communications Service Bureau. Cortex. https://www.gcsb.govt.nz/our-work/information-assurance/cortex/ last accessed 1st July 2019.

26 Computer Emergency Response Team (CERTNZ). Available at https://www.cert.govt.nz/ (accessed 1st July 2019).

27 Department of the Prime Minister and Cabinet. Refresh of New Zealand's Cyber Security Strategy and Action Plan. (Wellington: New Zealand Government, 2018), 6.

28 New Zealand Government. Strategic Defence Policy Statement. 2018: 39.

29 Sam Sherwood. Man accused of Christchurch mosque shootings pleads not guilty to 51 murder charges. Jun 14th 2019. Available at https://www.stuff.co.nz/national/christchurch-shooting/113473357/terror-accused-pleads-not-guilty-to-murder-charges (accessed 1st July 2019).

30 Ibid.,

31 Jacinda Arden. Prime Minister's speech at the National Remembrance Service. 29th March 2019.

Available at https://www.beehive.govt.nz/release/prime-minister $\% \mathrm{E} 2 \% 80 \% 99 \mathrm{~s}$-speech-national-remembrance-service (accessed 1st July 2019).

32 See https://www.classificationoffice.govt.nz/news/latest-news/christchurch-attacks-press-releases/ (accessed 5th July 2019).

33 Jacinda Arden and Stuart Nash. New Zealand bans military style semi-automatics and assault rifles. 21 st March 2019. Available at https://www.beehive.govt.nz/release/new-zealand-bans-military-stylesemi-automatics-and-assault-rifles (accessed 1st July 2019).

34 Jacinda Ardern. Christchurch Call to Eliminate Terrorist and Violent Extremist Online Content Adopted. May 16th 2019. Available at https://www.beehive.govt.nz/release/christchurch-call-eliminate-terrorist-and-violent-extremist-online-content-adopted last accessed 1st July 2019. See also https://www. christchurchcall.com/ (accessed 1st July 2019).

35 See https://christchurchattack.royalcommission.nz/ (accessed 1st July 2019).

36 See https://www.classificationoffice.govt.nz/news/latest-news/christchurch-attacks-press-releases/ (accessed 5th July 2019).

37 See https://www.christchurchcall.com/supporters.html (accessed 1st July 2019).

38 Royal Commission of Inquiry into the Attack on Christchurch Mosques on 15 March 2019 Order 2019 Available at http://www.legislation.govt.nz/regulation/public/2019/0072/latest/LMS183988.html?s$\mathrm{rc}=\mathrm{qs}$ (accessed 1st July 2019).

39 New Zealand Defence Force. Current Deployments. Available at http://www.army.mil.nz/about-us/ what-we-do/deployments/current-deployments.htm (accessed 1st July 2019).

40 Thomas Coughlan. NZ troops to return from Iraq, but Afghanistan stay extended. June 11th 2019 Available at https://www.newsroom.co.nz/2019/06/11/629718/nz-troops-to-return-from-iraq-but-afghanistan-stay-extended (accessed 1st July 2019).

41 New Zealand Government. Strategic Defence Policy Statement.

42 New Zealand Government. Defence Capability Plan. 
43 Ministry of Defence. The Climate Crisis: Defence Readiness and Responsibilities. December 2018. Available at https://www.defence.govt.nz/assets/Uploads/Climate-Change-and-Security-2018.pdf (accessed 25 th July 2019.

44 William Hoverd. Defence Capability Plan - Reading Between the Lines. 13th June 2019. https:// www.massey.ac.nz/massey/about-massey/news/article.cfm?mnarticle_uuid=F9252BA2-D7A4-4A57AC2F-1620500F49CE last accessed 1st July 2019.

45 Nicky Hager \& Jon Stephenson. 2017. Hit \& Run: The New Zealand SAS in Afghanistan and the meaning of honour. Potton and Burton Press, Nelson.

46 Inquiry into Operation Burnham. https://operationburnham.inquiry.govt.nz/ last accessed 1st July 2019.

47 See Hoverd, W., (Forthcoming 2019/20) Technological Threat Attribution, Trust and Confidence, and the Contestability of National Security Policy. In Reuben Steff (ed) Emerging Technologies and International Security: Machines, the State and War. Routledge, Studies in Conflict, Security and Technology series.

48 See: https://www.mpi.govt.nz/dmsdocument/26542-mycoplasma-bovis-2017-response-faqs last accessed 1st July 2019.

49 Ministry of Primary Industries. What is Mycoplasma Bovis? https://www.mpi.govt.nz/protection-and-response/mycoplasma-bovis/what-is-mycoplasma-bovis/ last accessed 1st July 2019.

50 Ibid.,

51 David Williams. M.Bovis Cost Passes 200 million dollars. June 25th 2019. https://www.newsroom. co.nz/2019/06/25/651872/mbovis-cost-passes-200m Last accessed 1st July 2019.

52 Ibid.,

53 Mycoplasma Bovis 2019 National Plan. https://www.mpi.govt.nz/dmsdocument/33708-m-bovis-2019-national-plan-summary last accessed 1st July 2019.

54 Ministry of Transport. Intelligent Traffic Systems. https:/www.transport.govt.nz/multi-modal/technology/intelligenttransportsystems/ last accessed 1st July 2019.

55 Department of Corrections. Intel Focus on Reducing Family Violence. https:/www.corrections.govt. nz/resources/newsletters_and_brochures/corrections_works/2016/corrections_works_march_2016/intel_focus_on_reducing_family_violence.html last accessed 1st July 2019.

56 Rob O’Neill. Customs targets social media for open source border security intelligence. 31 st July 2018. https://www.reseller.co.nz/article/644552/customs-targets-social-media-open-source-border-security-intelligence/ last accessed 1st July 2019.

57 Matt Stewart. Government launches new biosecurity intelligence unit. April 30th 2019. https://www.stuff. co.nz/environment/103487286/government-launches-new-biosecurity-intelligence-unit last accessed 1st July 2019.

58 Radio New Zealand. Government to question MBIE over fake persona training. 9th January 2019. https:/www.rnz.co.nz/news/political/379727/government-to-question-mbie-over-fake-persona-training Last accessed 1st July 2019.

59 Sir Michael Cullen and Dame Patsy Reddy. Intelligence and Security in a Free Society: Report of the First Independent Review of Intelligence and Security in New Zealand," 26th February 2016.

60 Ibid.,

61 The Intelligence and Security Act 2017.

62 The Act replaced: the New Zealand Security Intelligence Service Act 1969, the Government Communications Security Bureau Act 2003, the Intelligence and Security Committee Act 1996 and the Inspector-General of Intelligence and Security Act 1996.

63 The Inspector General of Intelligence and Security. http://www.igis.govt.nz/ last accessed 1st July 2019.

64 Rogers, D. (2018). Intelligence and Security Act 2017: A Preliminary Critique. New Zealand Law Review. 4, 657-692.

65 National Security System Handbook (Wellington: Department of the Prime Minister and Cabinet, 2016).

66 Johanson, TC. (2016). Weapon of Mass Distraction: New Zealand's National Security System. Democracy and Security. 13(2), 103-116. 
67 Department of Prime Minister and Cabinet. Officials' Committee for Domestic and External Security Coordination (Governance) (ODESC $(G)$ ) Available at https://dpmc.govt.nz/our-programmes/national-security-and-intelligence-oversight/national-security-governance-structure/odesc-governance-boards/ odesc-g (accessed 1st July 2019).

68 Department of Prime Minister and Cabinet. Strategic Risk and Resilience Panel. Available at https:// dpmc.govt.nz/our-programmes/national-security-and-intelligence-oversight/national-security-governance-structure/strategic-risk-and-resilience-panel (accessed 1st July 2019).

69 Department of Prime Minister and Cabinet. National security governance structure. Available at https://dpmc.govt.nz/our-programmes/national-security-and-intelligence/national-security-governance-structure (accessed 1st July 2019).

70 The Inspector General of Intelligence and Security. IGIS Reference Group. Available at http://www. igis.govt.nz/media-releases/announcements/igis-reference-group/ (accessed 1st July 2019).

71 See https://dpmc.govt.nz/sites/default/files/2018-01/ministerial-review-better-responses-natural-disaster-other-emergencies.pdf (accessed 1st July 2019).

72 Ibid.,

73 Ibid.,

74 W. Hoverd, (2017). "Differentiating Between New Zealand's two security studies research agendas", In W. Hoverd, N. Nelson, and C. Bradley, eds. New Zealand National Security: Challenges, Trends and Issues. (pp. 289 - 308). Auckland: New Zealand: Massey University Press.

75 Ibid., 300 .

76 See https://ebpc.org.nz/about-us/ (accessed 1st July 2019).

77 D. R, Rogers (2017). "New Zealand security intellectuals: Critics or courtesans?", in W. Hoverd, N. Nelson, \& C. Bradley, eds., New Zealand National Security: Challenges, Trends and Issues. (pp. 308 325). Auckland: New Zealand: Massey University Press.

78 Hoverd, W. (2017). Differentiating Between New Zealand's two security studies research agendas. In W. Hoverd, N. Nelson, \& C. Bradley (Eds.) New Zealand National Security: Challenges, Trends and Issues. (pp. 289 - 308). Auckland, New Zealand: Massey University Press. 298

79 Robert Lyon. (2019). Securitisation, Riskification and the Extension of "Security" Security Politics during the Key/English National Government. 149.798 Research Report. Massey University.

80 Line of Defence Magazine, Winter 2018 Volume 1 Issue 8.

81 William Hoverd, (2018). "Reflections on the Second National Security Conference", Line of Defence Magazine, Winter 2018 Volume 1 Issue 8.

82 See the Waikato Dialogue: The Implications of Emerging Disruptive Technologies for International Security and New Zealand, 20 September 2018. Available at https://www.waikato.ac.nz/fass/about/ social-sciences/political-science-and-public-policy/the-waikato-dialogue-symposium (accessed 1st July 2019).

83 See Centre of Defence and Security Studies "Security and Religion: Global and Local Perspectives" One Day Symposium. 1st May 2019, Wellington Campus.

84 Chris Rothery. 2018. New Zealand's National Security Framework: A recommendation for the development of a National Security Strategy. A thesis Submitted partial fulfilment of the requirements for the degree of Master of Arts in International Relations and Security Studies at The University of Waikato. 85 See Johanson, TC. (2016). Weapon of Mass Distraction: New Zealand's National Security System. Democracy and Security. 13(2), 103-116 and TC Johanson, (2017). "New Zealand's national security coordination”, In W. Hoverd, N. Nelson, \& C. Bradley, eds. New Zealand National Security Challenges, Trends and Issues. (pp. 237 - 253). Massey University Press.

86 Chris Rothery. (2019) “Time for a National Security Strategy”, National Security Journal, Massey University.

87 See https://christchurchattack.royalcommission.nz/ (accessed 1st July 2019). 